\title{
Umfang og áhrif mislingafaraldranna árin 1846 og 1882 á Íslandi
}

\author{
Sandra Gunnarsdóttir ${ }^{1}$ læknanemi, Haraldur Briem ${ }^{1,2}$ læknir, Magnús Gottfreðsson ${ }^{1,3}$ læknir
}

\section{ÁGRIP}

Inngangur: Mislingar hafa færst í vöxt sums staðar í hinum vestræna heimi og í mars 2014 greindist mislingatilfelli á Íslandi i fyrsta skipti frá árinu 1996. Sjúkdómurinn getur valdið dauða eða alvarlegum fylgikvillum og pví brýnt að minna á hversu skæður hann getur orðið og mikilvægi bólusetninga. Vegna einangrunar Íslands barst sjúkdómurinn sjaldan til landsins fyrir 20. öld. Faraldrar voru pví fáir en afar útbreiddir og mannskæðir. Sérstaða Íslands að pessu leyti gerir pað að verkum að auðvelt er að meta áhrif mislinga á fjölmennt, næmt pýði.

Efniviður og aðferðir: Frásagnir og lýðfræðileg gögn sýna að um mitt ár 1846 og 1882 bárust mislingar til landsins og voru báđir faraldrar afar mannskæðir. Í pessari rannsókn var leitast við að greina umfang og áhrif faraldranna tveggja með yfirferð kirkjubóka.

Niðurstöður: Í faraldrinum 1846 jókst fjöldi dauðsfalla mjög í júní og náđi hámarki i júlí pegar 741 einstaklingur lést, um fjórföld aukning umfram pað̃ sem vænta mátti. Faraldurinn var að mestu genginn yfir í desember. Staðbundinn faraldur geisaði á Austurlandi árið 1869. Faraldurinn árið 1882 hófst um mitt ár og náđi fjöldi dauðsfalla hámarki i júlí pegar 1084 létust. Pað var fimmföld aukning miðað við pað sem vænta mátti. Umframdánarhlutfall var hæst í N-Ísafjarðarsýslu, eða 4,7\%, en ekkert í A-Skaftafellssýslu par sem mislingar gengu 13 árum áđur. Peir sem létust í faraldrinum árið 1882 voru flestir í aldurshópnum 0-4 ára, eđa 64,6\%. Pá var dánarhlutfall kvenna á barneignaaldri rúmlega tvöfalt hærra en karla og fæðingatíđni 7-9 mánuðum eftir hámark 1882 faraldursins lækkaði marktækt um 50\%.

Ályktun: Pessi rannsókn varpar ljósi á alvarlegar afleiðingar mislinga í næmu pýði og sýnir verndandi áhrif hjarðónæmis. Unnt er að auðkenna flest dauðsföll mislingafaraldranna 1846 og 1882 á Íslandi.
'Læknadeild Háskóla
Íslands, ${ }^{2}$ Embætti landlæknis, ${ }^{3}$ Landspítala, Reykjavík Magnús Gottfreðsson magnusgo@landspitali.is

30. september 2013 sampykkt til birtingar

7. febrúar 2014.

Engin hagsmunatengsl gefin upp.

\section{Inngangur}

Mislingar eru bráđsmitandi sjúkdómur af völdum samnefndrar veiru. Sýkingin var algeng hjá börnum og olli árlega milljónum dauðsfalla á heimsvísu áđur en bóluefni kom til sögunnar á sjöunda áratug 20. aldar. Eftir að einstaklingur sýkist tekur við um 10 daga meðgöngutími. Í kjölfarið kemur fram hiti, hósti, nefkvef og tárubólga. ${ }^{1}$ Eftir pessi fyrirboðaeinkenni koma fram rauðir upphleyptir flekkir, fyrst á andliti og fyrir aftan eyrun en dreifa sér síðan um búkinn og útlimi. Pessi útbrot standa yfir í 3-5 daga og hverfa í sömu röð og pau komu fram. ${ }^{1}$ Ef engin eftirmál verða vegna sýkingarinnar hefst afturbati oftast rétt eftir að útbrotin koma fram. Ónæmisbæling sem verður í kjölfar sýkingarinnar verður pó til pess að margir eru lengi að jafna sig og hætt er við ýmsum tækifærissýkingum. Hún stendur yfir í nokkrar vikur og jafnvel mánuði.,3 Sumir fá alvarlega og jafnvel banvæna fylgikvilla eins og skæðar lungnabólgur og miðtaugakerfissýkingar. Enn er óljóst hvers vegna sumir virðast sleppa betur frá sýkingunni en aðrir. Nokkrir mögulegir pættir hafa verið nefndir, svo sem vannæring, ónæmisfræðilegir pættir og veirumagn við sýkingu. ${ }^{4-7}$ Dánartíðni vegna mislinga er hæst hjá börnum undir 5 ára aldri en einnig hefur verið sýnt fram á skaðleg áhrif mislinga á barnshafandi konur. Mislingar geta haft skaðleg áhrif á bæði móður og fóstur og auka líkurnar á ótímabærum fæðingum..$^{8-10}$ Hægt er að koma í veg fyrir mislinga með bóluefni sem veitir flestum ævilangt ónæmi. Mislingaveiran var einangruð af John Enders árið 1954 og lifandi veiklað bóluefni gegn mislingum var sett á markað árið 1963 í Bandaríkjunum. ${ }^{11}$ Bóluefni gegn mislingum kom fyrst til landsins frá Bandaríkjunum árið 1966 og var pví dreift til héraðslækna víðs vegar um landið. Ekki var um skyldubólusetningu að ræða heldur gátu peir sem vildu látið bólusetja sig gegn gjaldi. ${ }^{12}$ Árið 1976 hófst mislingabólusetning við tveggja ára aldur. ${ }^{13}$ Árið 1989 hófst bólusetning með prígildu bóluefni gegn mislingum, hettusótt og rauðum hundum (Measles, Mumps and Rubella vaccine, eða MMR bóluefni) og gefið við 18 mánaða aldur. Árið 1994 var ákveðin endurbólusetning við 9 ára aldur og 2001 var hún færð upp í 12 ára aldur. Í mars 2014 greindust mislingar á Íslandi í fyrsta skipti frá árinu 1996. ${ }^{14}$

Prátt fyrir að mislingar séu sjúkdómur sem ætti í raun að vera hægt að útrýma með bólusetningum, eru mislingafaraldrar enn algengir víða um heim. Grunnútbreiðslutala, eða $\mathrm{R}_{0}$ fyrir mislinga, er á bilinu 15-25 (meðalfjöldi peirra sem smitast af einum sjúklingi með sjúkdóminn, að pví gefnu að allir séu næmir), sem sýnir fram á hve sjúkdómurinn er gríðarlega smitandi en samkvæmt pessu er nóg að 5\% pjóðar sé næm fyrir sjúkdómnum svo faraldrar geti myndast. ${ }^{15}$ Pau lönd innan Evrópusambandsins og Evrópska efnahagssvæðisins par sem flest mislingatilfelli á hverja milljón íbúa voru tilgreind frá apríl 2012 til mars 2013 voru Bretland, Rúmenía, Írland, Frakkland og Belgía. ${ }^{16}$ Einnig var stór hópsýking af mislingum í Sviss árið 2011 par sem 219 tilfelli voru tilgreind (47 tilfelli á hverja 100.000 íbúa). 
Mynd 1. Hér sést manntalsskýrsla Snxfells- og Hnappadalsprófastsdxmis fyrir árið 1846, rituð af Pétri Péturssyni si̊̋ar biskupi. Ljósmyndina tók Sandra Gunnarsdóttir á Pjóoskjalasafni Íslands.

Par var í $81 \%$ tilfella um óbólusetta einstaklinga að ræða og $8 \%$ sem ekki voru bólusettir að fullu. ${ }^{17}$ Pessa faraldra má pví að stórum hluta rekja til ófullnægjandi pátttöku í bólusetningum, en möguleg skaðleg áhrif bóluefna hafa valdið mörgum foreldrum áhyggjum,

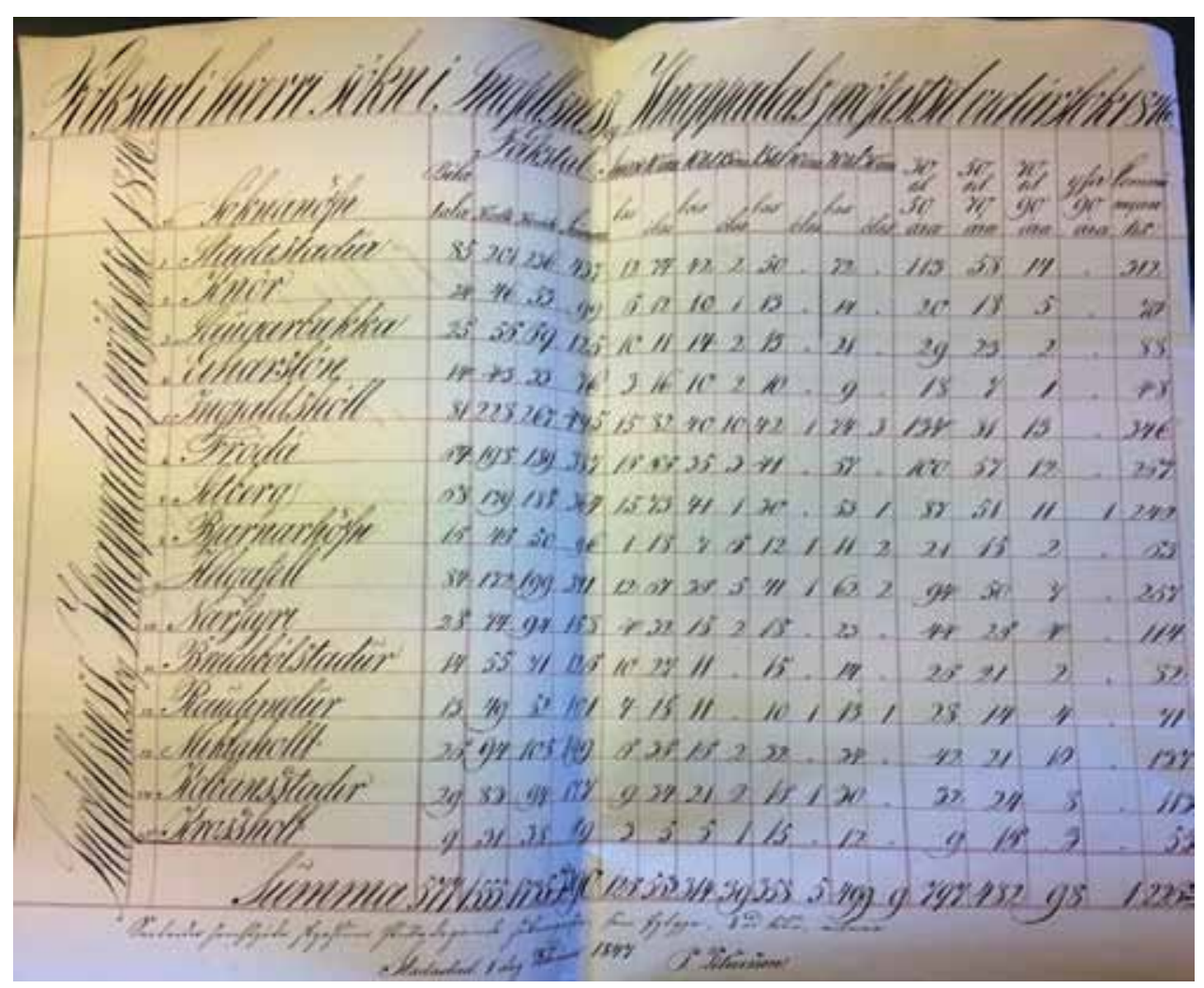
einkum tengsl við einhverfu. Engin slík tengsl hafa fundist. ${ }^{18}$

Faraldsfræði mislinga á Íslandi er um margt sérstök vegna einangrunar landsins og hins langa tíma sem oft leið á milli faraldra. Í heilbrigðisskýrslum Íslands má finna yfirgripsmiklar sögulegar heimildir og nákvæmar landfræðilegar upplýsingar um skæða faraldra, sem hafa verið erlendum rannsakendum á sviði faraldsfræði hugleikið rannsóknarefni. ${ }^{19,20}$ Engu að síður hafa mislingafaraldrar 19. aldar hér á landi verið fremur lítið rannsakaðir. Pótt gögn úr heilbrigðisskýrslum séu um margt ítarleg, er par ekki unnt að finna upplýsingar um aldur, kyn og búsetu peirra sem létust úr skæðum farsóttum á árum áđur. Slíkar upplýsingar má hins vegar nálgast í kirkjubókum og manntölum, sem eru vannýttar heimildir í læknisfræðirannsóknum hér á landi (mynd 1). Á 19. öld komu mislingar sjaldan til landsins og pví var stórt hlutfall pjóðarinnar næmt fyrir veirunni hverju sinni. Pess vegna var sjúkdómurinn ekki landlægur hér á landi heldur barst hingað með skipum á margra ára fresti. Einangrun var beitt en pegar slík viðbrögð brugðust var veiran fljót að dreifa sér svo úr varð mannskæður faraldur. Stærstu mislingafaraldrar sem sögur fara af hér á landi voru árin 1846 og 1882. Pegar um afar bráđar en skammvinnar farsóttir er að ræða skapa kirkjubækurnar tækifæri til pess að búa til lista yfir pá sem líklega létust úr slíkum sjúkdómum, löngu eftir að faraldrarnir eru um garð gengnir. ${ }^{21}$ Slíkir listar geta pví varpað ljósi á afleiðingar pess er stór hópur næmra einstaklinga er útsettur fyrir skæðri veiru á sama tíma. Hér verður faröldrum 19. aldar gerð skil með vísan til íslenskra samtímaheimilda, einkum kirkjubóka og tímarita.

\section{Efni og aðferdir}

Yfirlestur og skráning gagna

Á Pjóðskjalasafni Íslands er að finna kirkjubækur frá 18.-20. öld. Í pær skráðu sóknarprestar niður upplýsingar um fædda, fermda, gifta, burtvikna, innkomna og látna. Par er að finna persónugreinanlegar upplýsingar, par með talið nafn, fæðingar- og dánardag, búsetu og stundum dánarorsök. Fengið var yfirlit hjá Pjóðskjalasafni Íslands um allar pær sóknir sem á landinu voru á árunum 1845-47 og 1881-83 og kirkjubækur peirra sókna yfirfarnar. Af peim 205 kirkjubókum sem voru skráðar fyrir árin 1845-47 voru 8 ekki til staðar, eða tæp 4\%. Af peim 188 kirkjubókum sem voru skráðar fyrir árin 1881-83 voru 13 ekki til staðar, eða tæp 7\%. Pví má gera ráð fyrir að dauðsföll hafi verið fleiri en pessi rannsókn sýnir. Upplýsingar um látna og mannfjölda eftir sóknum og sýslum voru fengnar úr fáanlegum kirkjubókum og handskrifuðum manntalsskýrslum á Pjóðskjalasafni Íslands, sem og riti Hagstofunnar, Hagskinnu. Hluti af pessum opinberu upplýsingum var yfirfarinn og skráđur á tölvutækt form. Tölulegar upplýsingar um mannfjölda, fæðingar- og dánartíðni voru fengnar úr gögnum Hagstofu Íslands. Greinargóðar lýsingar í Heilbrigðisskýrslum landlæknis og héraðslækna voru einnig skoðaðar, auk gamalla tímarita, bóka og greina.

\section{Úrvinnsla og tölfræði}

Fjöldi einstaklinga sem lést í hverjum mánuði pað ár sem faraldurinn geisaði var skráður niður og til samanburðar sá fjöldi sem lést árið á undan og eftir. Faraldarnir báðir gengu yfir á nokkrum mánuðum á árunum 1846 og 1882. Mislingarnir komu að vori til og voru um garð gengnir við árslok. Vitað er að mislingar bárust hvorki til landsins 1845 né 1847, sama gildir um árin 1881 og 1883. Pví var ákveðið að bera pau ár saman við mislingaárin 1846 og 1882. Dregin er sú ályktun að hinn aukni fjöldi dauðsfalla sem sést á peim tímabilum sem mislingarnir herjuðu á pjóðina, sé vegna mislinganna. Reiknað var út umframdánarhlutfall (excess mortality) eftir sýslum fyrir pau tímabil er faraldararnir stóðu sem hæst á eftirfarandi hátt: Faraldurinn 1846 stóð yfir í um 7 mánuði (júní til desember). Meðalfjöldi dauðsfalla yfir 7 mánuði í hverri sýslu árin 1844-45 var dreginn frá fjölda dauðsfalla í júní til desember í hverri sýslu árið 1846. Sá fjöldi var reiknaður sem hlutfall af mannfjölda í hverri sýslu árið 1845. Sömu aðferð var beitt fyrir síðari 


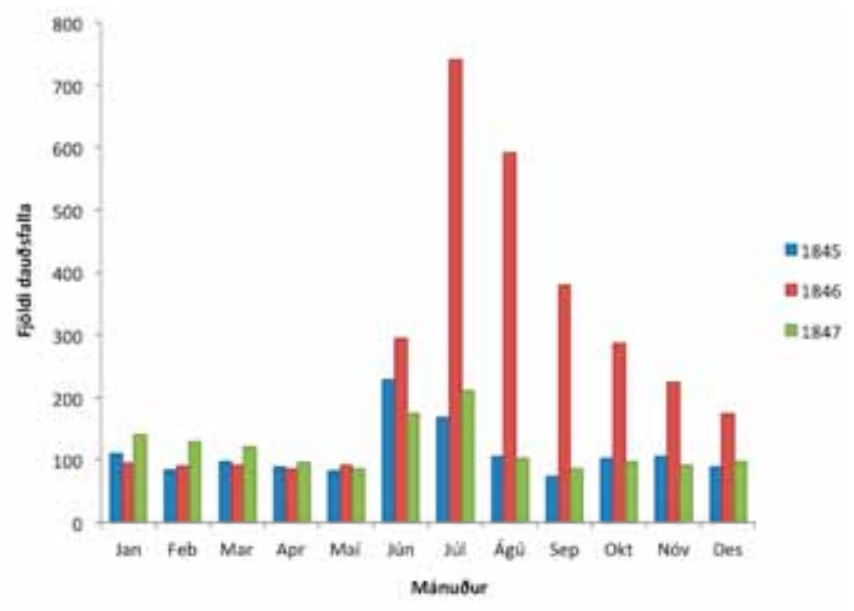

Mynd 2. Fjöldi dauðsfalla í hverjum mánuði árin 1845-1847.

faraldurinn 1882. Hann stóð yfir í um prjá mánuði og meðalfjöldi dauðsfalla yfir prjá mánuði í hverri sýslu árin 1880-81 var dreginn frá fjölda dauðsfalla í júní til ágúst í hverri sýslu árið 1882. Notast var við manntalsskýrslu frá 1880. Meðalfjöldi fæðinga eftir mánuðum árin 1877-1881 var fenginn úr gögnum Hagstofu Íslands og reiknað 95\% öryggisbil. Áhrif faraldursins 1882 voru metin með pví að bera saman fjölda fæðinga næstu 12 mánuði eftir að faraldurinn náði hámarki, við meðalfjölda fæðinga árabilið 1877-1881.

\section{Niðurstöठur}

Faraldurinn 1846 - sögulegt yfirlit

Í upphafi ársins 1846 voru Íslendingar 58.667 talsins. Síðar pað sama ár geisaði annar af tveimur stærstu mislingafaröldrum á Íslandi fyrr og síðar. Mislingarnir bárust til landsins með Dönum sem komu í höfn í Hafnarfirði pann 20. maí. ${ }^{22,23}$ Veikin dreifði sér hratt paðan um allt landið. Раð var talið til tíðinda ef einn eða tveir í heilli kirkjusókn fengu ekki mislinga. Fjöldi dauðsfalla jókst mjög tímabilið frá júní og til ársloka, en náði hámarki í júlí. Peir pjóðfélagshópar sem urðu verst úti voru börn undir priggja ára aldri, fólk yfir fimmtugt og drykkjumenn. ${ }^{22}$ Í ársritinu Gesti Vestfirðingi árið 1847 er ritað að í júní 1846 hafi mislingar borist með skólapiltum til Vestfjarða og fólk veikst í hrönnum: „[H]ún hlífði eingum manni, lagðist fólk svo gjörsamlega, að margir voru peir

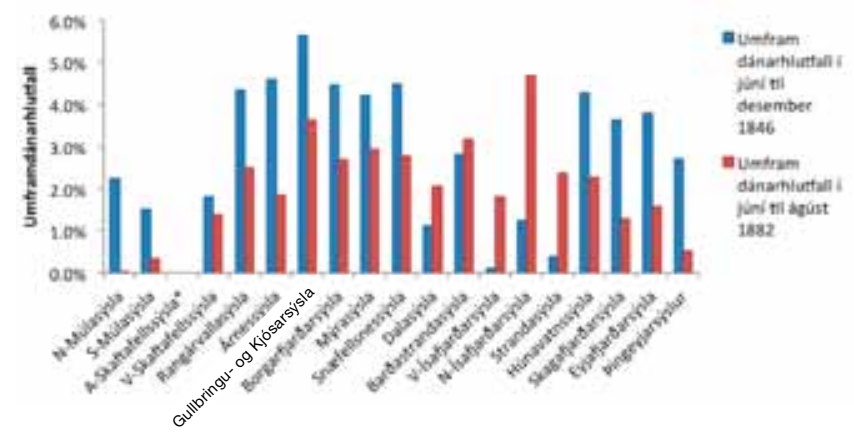

Mynd 4. Umframdánarhlutfall í sýslum landsins pá mánuð̄i pegar mislingafaraldrar 19. aldar gengu yfir landiðárin 1846 og 1882. *I A-Skaftafellssýslu var umframdánarhlutfall ekkert.

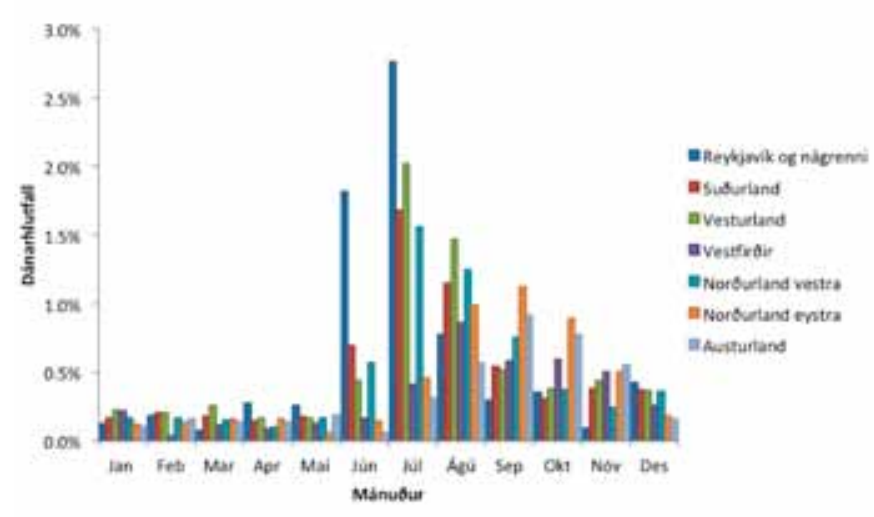

Mynd 3. Útbreiðsla faraldursins 1846. Grafið sýnir dánarhlutfall í landshlutum Íslands árið 1846.

bæir, par er hvorki varð gegnt heyvinnu né öðrum atvinnuvegum í tvær eða prjár vikur, og sumstaðar kvað svo mikið að sóttveiki manna, að um tíma varð hvorki búsmali hirtur né sjúklingum aðhjúkrað.“ Fjöldi dauðsfalla af völdum sýkingarinnar var misjafn í sveitum, 5-6 af hverjum 100 létust í sumum peirra. Á pessum tíma geisaði sóttin einnig í Færeyjum. Par var hún svo slæm að af 800 manns sem bjuggu í Pórshöfn veiktust 700 á stuttum tíma og margir létust í júní. Petta var í fyrsta skipti sem mislingar bárust til Færeyja frá árinu 1781. ${ }^{23}$ Samkvæmt grein í bjóðólfi sem birt var við upphaf mislingafaraldursins 1882 var árið 1846 pað mannskæðasta af pví sem liðið var af 19. öld. Pá létust rúmlega 2000 fleiri en vanalega, en næst pví komst árið 1843 (kvefsóttarár) pegar aukning dauðsfalla var rúmlega 1900 manns umfram meðaltal. ${ }^{22}$

\section{Faraldurinn 1846 - töluleg gögn úr kirkjubókum}

Alls fækkaði Íslendingum um rúmlega 2\% árið 1846, en pað ár létust rúmlega 3300 Íslendingar. Рað er 1600-2000 manns umfram pað sem vænta mátti. Fjöldi dauðsfalla eftir mánuðum árin 1845-1847 er sýndur á mynd 2. Árin á undan og eftir faraldrinum eru sýnd til samanburðar. Á myndinni sést að faraldurinn náði hámarki í júlí 1846. Pá lést 741, rúmlega fjórfalt fleiri en sama mánuð árið á undan og 3,5-falt fleiri en sama mánuð árið eftir. Faraldurinn var víðast hvar farinn að hjaðna í desember (mynd 2). Мeð pví að skoða mánaðarlegt dánarhlutfall í hverri sýslu má sjá útbreiðslu faraldursins yfir landið. Bylgjan færðist í báðar áttir út frá Reykjavík og nágrenni, en stöðvaðist við mót Suðurlands og Austurlands en hélt áfram réttsælis hringinn um landið (mynd 3). Dánarhlutfall náði síðast hámarki á Norðurlandi eystra og Austurlandi. Umframdánarhlutfall eftir sýslum er sýnt á mynd 4. Eins og sjá má var ekkert umframdánarhlutfall í A-Skaftafellssýslu sem var mjög strjálbýl, en hæst í Gullbringu- og Kjósarsýslu.

\section{Faraldurinn 1882 - sögulegt yfirlit}

Árið 1882 bárust mislingar til Íslands með Helga Helgasyni snikkara, sem kom frá Kaupmannahöfn með póstskipinu Valdemar. ${ }^{24}$ Skipið lét úr höfn 15. apríl frá Danmörku ${ }^{22,25}$ en mislingafaraldur hafði gengið par í febrúar sama ár. ${ }^{26}$ Skipið kom til Reykjavíkur 


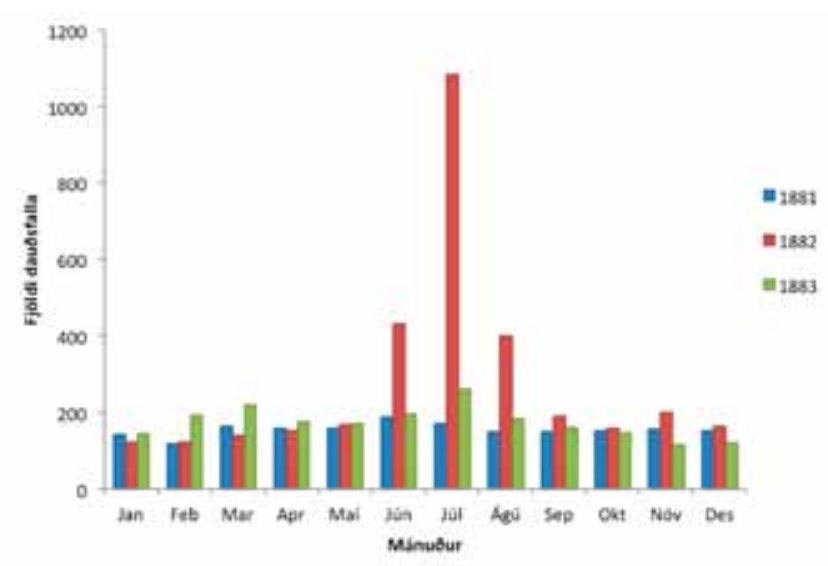

Mynd 5. Fjöldi dauðsfalla á Î́landi í hverjum mánuð̃ árin 1881 - 1883.

2. maí og varð par faraldur í kjölfarið sem breiddist út um allt land. ${ }^{22,24,27}$ Helgi fann fyrir slappleika á leiðinni til Íslands og fór beinustu leið í lyfjabúðina við Thorvaldsenstræti pegar hann kom á land. Par hitti hann Jón Tómasson afgreiðslumann og bað hann um eitthvað hressandi pví að „slen“ væri í sér. Tveimur dögum síðar komu útbrot fram á Helga og hann varð pað slappur að hann lagðist í rúmið. Við petta fóru viðvörunarbjöllur í gang og hús Helga var sett í einangrun með pað að markmiði að stöðva útbreiðslu mislinganna. ${ }^{26}$ Pessar aðferðir dugðu ekki til, enda hafði Helgi farið víða og nánast óhjákvæmilegt að hann hefði smitað fleiri áður en hann lagðist. Afgreiðslumaður lyfjabúðarinnar lagðist næst, síðan bæjarbúar hver á fætur öðrum. ${ }^{24}$ Jónas Jónassen landlæknir sendi út rit til að sporna gegn útbreiðslu mislinganna en allt kom fyrir ekki. Sóttin gerði fljótlega vart við sig í Latínuskólanum. Kennsla féll niður og flestum vorprófum frestað til næsta hausts. Um pað leyti sem Latínuskólanum var lokað var talið að 1000-1100 manns hefðu fengið mislingana. Illvíg lungnabólga var algengur fylgikvilli. Margir fengu slæman hlustarverk og misstu heyrn um tíma og sumir misstu sjón. „Breitt var fyrir alla glugga, pví sjúklingar poldu illa birtuna, og pegar komið var inn í húsin heyrðist ekki annað en veikindastunur í hálfrökkrinu."24 Talið var að nær allir peir sem ekki höfðu fengið mislinga áður hafi veikst. Pungaðar konur urðu hvað verst úti, ásamt ungbörnunum, og mislingarnir höfðu pau áhrif að pær fæddu iðulega fyrir tímann. Mörg börn fæddust pví andvana og margar mæður létust af barnsförum. Samkvæmt Porvaldi Jónssyni, héraðslækni á Ísafirði árið 1882, var veikin sérstaklega hættuleg ungbörnum, veikluðu fólki og barnshafandi konum. Flestar barnshafandi konur misstu fóstur eða fæddu fyrir tímann og flest pau börn létust. ${ }^{24,28}$ Árið 1882 var erfitt að mörgu leyti. Sumarið var óvenjukalt og samgöngur erfiðar. Ekki var hægt að fá mat frá útlöndum vegna samgönguleysis og matvælaskortur var í verslunum víðs vegar um landið. Ofan á allt bættust mislingarnir. ${ }^{24}$

Faraldurinn 1882 - töluleg gögn úr kirkjubókum

Fjöldi dauðsfalla eftir mánuðum árin 1881-1883 er sýndur á mynd 5. Sjá má að fjöldi dauðsfalla náði hámarki í júlí 1882, pegar 1084 létust. Рað var rúmlega sexföld aukning á fjölda dauðsfalla miðað við sama mánuð árið á undan og rúmlega fjórföld aukning miðað við árið á eftir. Alls létust 1916 manns í júní, júlí og ágúst árið 1882

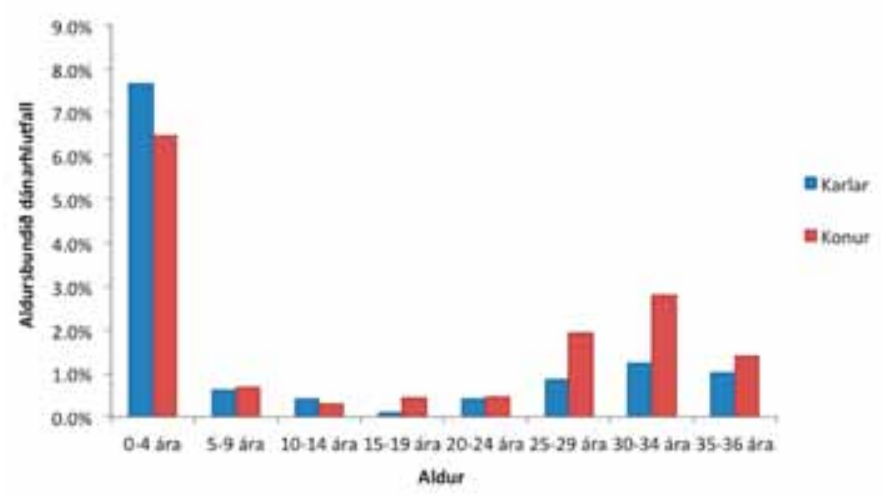

Mynd 6. Aldurs- og kynbundið dánarhlutfall Íslendinga á aldrinum 0-36 ára, er létust í júní, júlí og ágúst árið 1882.

en aðeins 507 og 637 pessa sömu mánuði árin 1881 og 1883 hvort um sig. Umframdánarhlutfall eftir sýslum meðan faraldurinn stóð sem hæst er sýnt á mynd 4. Eins og sjá má af myndinni var hlutfallið lægst í Pingeyjarsýslum, Múlasýslum og A-Skaftafellssýslu. Sýslan með hæsta umframdánarhlutfallið árið 1882 var N-Ísafjarðarsýsla. Sú sýsla var með fimmta lægsta dánarhlutfallið árið 1846.

Aldurs- og kynbundin dánartíðni Íslendinga sem létust á meðan faraldurinn stóð sem hæst er sýnd á mynd 6. Sjá má að stærsti hlutinn voru börn, 0-4 ára, og konur á barneignaaldri voru í meirihluta miðað við karla á sama aldri. Samkvæmt gögnum Hagstofunnar var meðalfjöldi látinna barna á fyrsta aldursári árin 1877-1881 386 börn á ári, en alls létust 1010 börn á fyrsta aldursári árið 1882. Ef gögn um fjölda fæðinga eru skoðuð sést að peim fækkaði mjög pegar faraldurinn náði hámarki, en einnig kemur fram 50\% fækkun 7-9 mánuðum síðar (mynd 7).

\section{Umræða}

Í pessari grein hefur verið leitast við að lýsa tveimur af stærstu mislingafaröldrum sem pekktir eru með vissu hér á landi. Prátt fyrir að aðstæður séu nú gerbreyttar frá 19. öld pegar Ísland var

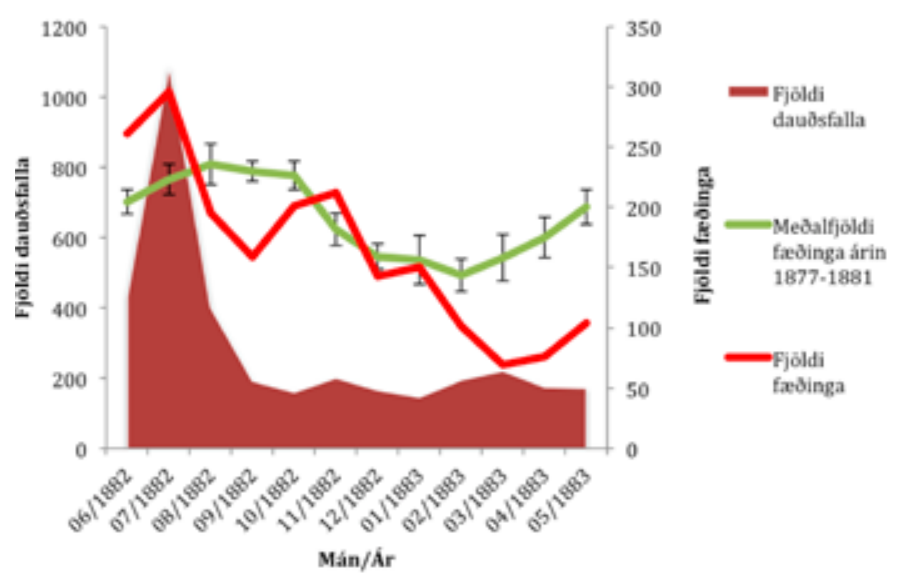

Mynd 7. Áhrif mislingafaraldursins 1882 á fjölda fxðinga árið 1883. Rauðbrúna flatarmálsgrafið sýnir fjölda dauðsfalla frá júní 1882 til og með maí 1883. Græna línan sýnir meðalfjölda fæðinga í hverjum mánuði á 5 ára tímabilinu 1877-1881 með 95\% öryggisbili. Rauða línan sýnir fjölda fæððinga frá júní 1882 til maí 1883. 
vanpróað ríki að nánast öllu leyti, varpa pessi sögulegu gögn skýru ljósi á umfang og afleiðingar mislinga pegar peir berast í næmt pýði. Líklegt verður pó að telja að bágborið heilsufar, næringarástand, húsakostur og lítil heilbrigðispjónusta hafi ráðið allmiklu um pað hversu gríðarlega margir Íslendingar létust í pessum faröldrum, en peir voru margfalt fleiri en peir sem létust í spænsku veikinni. ${ }^{24,29}$ Í grein í Đjóðólfi frá árinu 1882 er talað um að ein orsökin fyrir pví að mislingasóttin 1846 varð svo skæð hafi verið sú að oft fékk hvert einasta barn á heimilum sýkina á sama tíma, svo að á mörgum bæjum lágu heimilisstörf niðri. Allir lágu rúmfastir í einu svo að dagleg störf voru ekki unnin og jafnvel ekki mögulegt að hjúkra hinum sjúku. Um leið og bráði af fólki varð pað að taka til starfa og sjá fyrir heimilinu. Við pað tók sóttin sig gjarnan upp aftur, pá jafnvel með tilheyrandi fylgikvillum mislingasýkingar, til að mynda lungnabólgu, sem varð mörgum banvæn. Sýkinni gat fylgt hálsbólga, augnveiki, höfuðverkur, hósti, brjóstpyngsli og fleira og stundum mikill niðurgangur sem varð mörgum að bana. ${ }^{22}$ Síðari tíma fræðimenn hafa sett fram pá kenningu að sýkingin kunni að vera pví illvígari í barnmörgum fjölskyldum vegna aukins smitskammts við slíkar aðstæður.7 Ein áleitin spurning lýtur að vægi erfðapátta í tilurð sjúkdómsins. Hvort hugsanlegt sé að ákveðnir einstaklingar séu í aukinni hættu á að fá lífshættulega fylgikvilla sjúkdómsins. Pær skráningar sem er að finna í hinum gömlu kirkjubókum geta hjálpað okkur að svara peirri spurningu.

Pegar borinn er saman tíminn sem pað tók faraldurinn 1846 að breiðast út um landið, vekur athygli hversu hratt pað gerðist, prátt fyrir lélegar samgöngur. Eins og vænta mátti staðnæmdist faraldurinn við Skeiðará, en barst réttsælis til Austurlands. Einnig er áhugavert að skoða hversu misjafnt pað var eftir landsvæðum hve langur tími leið par til faraldurinn náði hámarki. Í Reykjavík og nágrenni var útbreiðsluhraðinn mestur. Leiða má líkur að pví að péttbýlið í Reykjavík hafi flýtt mjög fyrir útbreiðslunni, enda berast farsóttir almennt hægar út í strjálbýli og geta jafnvel stöðvast. Á Austurlandi var stígandi hægastur, enda var par oft langt á milli bæja og landshlutinn víðfeðmur. Faraldurinn 1882 gekk hraðar yfir en faraldurinn 1846, mögulega vegna betri samgangna pó erfitt sé að segja til um pað. Hann gekk yfir á premur mánuðum á meðan faraldurinn 1846 virðist hafa náð að teygja sig yfir um 6 mánuði.

Samanburður á umframdánarhlutfalli eftir sýslum sýnir sterkar vísbendingar um mikilvægi ónæmis í mislingum. Vitað er að mislingafaraldur gekk yfir Austurland 1868-70. Pá komu mislingarnir með frönsku fiskiskipi á Langanes og dreifðu sér um Pingeyjarsýslur og Austurland..$^{30}$ Gera má ráo fyrir að fremur lág dánartíðni á Austurlandi árið 1882 geti skýrst af pessu. Rannsókn á mislingafaraldri í Færeyjum árið 1846 er talin vera ein sú fyrsta sem sýndi fram á ónæmisfræðilegt minni líkamans gagnvart sjúkdómnum. Danski læknirinn Peter Ludwig Panum tók eftir pví að peir sem höfðu fengið mislinga sem bárust til eyjanna 1781 smituðust ekki árið $1846 .{ }^{31}$ Samanburður á umframdánarhlutfalli eftir sýslum á Íslandi í faraldrinum 1846 sýnir að innbyrðis munur eftir sýslum var mun minni en árið 1882. Heimildir um mislingafaraldra á 18. öld á Íslandi eru afar stopular og mislingum var gjarnan ruglað saman við rauða hunda og skarlatsótt. ${ }^{32}$ Fræðimönnum ber til að mynda ekki saman um pað hvort mislingar hafi borist til landsins árið 1798, en jafnvel pótt svo hafi verið má gera ráð fyrir að mögu- leg áhrif af hjarðónæmi vegna faraldurs pað ár hafi verið fremur takmörkuð árið 1846, nær hálfri öld síðar.

Ljóst er að áhrif mislingafaraldranna beggja voru gríðarleg, en pó er munur á. Árið 1846 höfðu mislingar ekki borist til Reykjavíkur í að minnsta kosti 48 ár og hugsanlega lengur. Í peim faraldri var algengt að allir á heimilinu veiktust á sama tíma svo að öll atvinna lá niðri. ${ }^{24,25}$ Í faraldrinum 1882 voru flestir 36 ára og eldri pegar búnir að fá sjúkdóminn og gátu hjúkrað hinum sjúku og hefur hugsanlega munað um pað.

Við skoðun á aldursbundnu dánarhlutfalli pegar faraldurinn 1882 gekk yfir, sést að yngsti aldurshópurinn, 0-4 ára, kemur hvað verst út (mynd 6). Á 19. öld var ungbarnadauði mun hærri en pekkist í dag, en ef skoðaður er meðalfjöldi látinna barna á fyrsta aldursári 5 árum fyrir faraldurinn 1882 (1877-1881) er fjöldinn 2,6-falt lægri en mislingaárið 1882.

Við skoðun okkar á fæðingartíðni í kjölfar faraldursins 1882 má merkja gríðarlega fækkun í fæðingum í kjölfarið. Má álykta að allstór hluti kvenna á barneignaaldri sem lést pegar faraldurinn gekk yfir landið 1882 hafi verið barnshafandi. Fækkunina í fæðingum árið 1883 mætti pví skýra með pví að umræddar konur hafi misst fóstur eða hreinlega látist. Petta er í samræmi við niðurstöður annarra rannsókna sem hafa sýnt fram á skaðleg áhrif mislinga á barnshafandi konur. ${ }^{8-10}$ Athygli vekur að toppur sást í fjölda fæðinga pegar faraldurinn var í hámarki í júlí árið 1882. Vitað er að mislingar höfðu oft pau áhrif á barnshafandi konur að pær fæddu fyrir tímann. Pessi toppur gæti pví mögulega verið vegna fjölda ótímabærra fæðinga, en gríðarleg fækkun fæðinga kemur fram 7-9 mánuðum síðar, sem væntanlega skýrist af hvoru tveggja, dauðsföllum barnshafandi kvenna og fósturlátum.

Mislingaárið 1882 létust um 1300 fleiri en búast mátti við hér á landi. Í yfirliti yfir mannfjölda í sýslum sem birt var árið 1891 í tímaritinu Ísafold var borinn saman íbúafjöldi árið 1880 við íbúafjölda 1. nóvember árið 1890. Í sumum sýslum varð vart við fólksfækkun en mesta fólksfjölgunin var í Gullbringu- og Kjósarsýslu og Ísafjarðarsýslum. Pegar hart var í ári var algengt að fólk yfirgæfi sveitabúskapinn og flykktist að sjónum, en fyrrnefndar sýslur höfðu einmitt að geyma helstu fiskipláss landsins. Pótt straumurinn hafi verið mikill úr sveitunum í sjávarplássin á harðindatímabilinu 1882-1887, var hann pó margfalt meiri af landi brott, nánast eingöngu til Vesturheims. Ein orsök fólksfækkunarinnar var pví brottflutningur fólks til Vesturheims. ${ }^{33}$

Einnig má velta fyrir sér óbeinum áhrifum mislinganna á fólksfækkun á Íslandi. Ekki er ósennilegt að dauðsföll innan fjölskyldna, fráfall foreldra, maka eða barna hafi valdið losi í fjölskyldum og sumir peirra sem eftir lifðu hafi viljað leita á önnur mið.

Ljóst er að mislingafaraldrar 19. aldar voru gríðarlega mannskæðir. Í mars 2014 greindist mislingatilfelli á Íslandi i fyrsta skipti frá árinu 1996. Nauðsynlegt er að fylgjast vel með gangi mála og halda bólusetningartíðni í hámarki, sérstaklega í ljósi pess að faraldrar eru að koma upp víða í Evrópu í dag. Einnig parf að hafa í huga að enginn núlifandi einstaklingur hefur upplifað mislinga í líkingu við mislingafaraldra 19. aldar. Alvarleiki sjúkdómsins hefur pví líklega fallið í gleymsku hjá mörgum. Pví er mikilvægt að auka vitund almennings um sjúkdóminn pví mögulegt er að margir haldi að um saklausan útbrotasjúkdóm sé að ræða og pví óparfi að bólusetja börn gegn honum. 
Pessar niðurstöður minna okkur á mikilvægi hjarðónæmis og pá miklu hættu sem stafar af mislingum ef ekki næst að halda pví nægilega háu. Nánari skoðun á fjölskyldutengslum og skyldleika væri afar áhugaverð með aðferðum sem áður hefur verið lýst í rannsóknum á spönsku veikinni. Upplýsingar sem leynast í gömlum íslenskum kirkjubókum gefa okkur kost á pví að svara grundvallarspurningum um pessa skæðu mislingafaraldra, meira en 130 árum síðar.

\section{Pakkir}

Jón Torfason skjalavörður á Pjóðskjalasafni Íslands fær pakkir fyrir aðstoð við öflun gagna.

\section{Heimildir}

1. Moss WJ Griffin DE. Measles. Lancet 2012. 379: 153-64.

2. Coovadia HM, Wesley A, Henderson LG, Brain P, Vos GH Hallett AF. Alterations in immune responsiveness in acute measles and chronic post-measles chest disease. Int Arch Allergy Appl Immunol 1978; 56: 14-23.

3. Tamashiro VG, Perez HH, Griffin DE. Prospective study of the magnitude and duration of changes in tuberculin reactivity during uncomplicated and complicated measles. Pediatr Infect Dis J 1987; 6: 451-4.

4. Dossetor J, Whittle HC, Greenwood BM. Persisten measles infection in malnourished children. Br Med J 1977; 1: $1633-5$.

5. Oldstone MB, Dales S, Tishon A, Lewicki H, Martin L. A role for dual viral hits in causation of subacute sclerosing panencephalitis. J Exp Med 2005; 202: 1185-90.

6. Coulter JB, Balch N, Best PV. Subacute sclerosing panencephalitis after drug-induced immunosuppression. Arch Dis Child 1979; 54: 640-2.

7. Aaby P, Bukh J, Lisse IM, Smits AJ. Measles mortality, state of nutrition, and family structure: a community study from Guinea-Bissau. J Infect Dis 1983; 147: 693-701.

8. Eberhart-Phillips JE, Frederick PD, Baron RC, Mascola L. Measles in pregnancy: a descriptive study of 58 cases. Obstet Gynecol 1993; 82: 797-801.

9. Chiba ME, Saito M, Suzuki N, Honda Y, Yaegashi N Measles infection in pregnancy. J Infect 2003; 47: 40-4.
10. Atmar RL, Englund JA, Hammill H. Complications of measles during pregnancy. Clin Infect Dis 1992; 14: 217-26.

11. Katz SL. John F. Enders and measles virus vaccine--a reminiscence. Curr Top Microbiol Immunol 2009; 329: 3-11.

12. [Anonymous]. Bólusetning gegn mislingum hafin hjá héraðslæknum. Morgunblaðið 1966; 53(229): 27-8.

13. Johnsen, SJ. Síðasti mislingafaraldurinn? Heilbrigðismál 1977; 25: 29.

14. landlaekniris - mars 2014

15. Rohani P, Earn DJ, Grenfell BT. Opposite patterns of synchrony in sympatric disease metapopulations. Science 1999; 286: 968-71.

16. ecdc.europa.eu - júlí 2013

17. Delaporte E, Wyler Lazarevic CA, Iten A, Sudre P. Large measles outbreak in Geneva, Switzerland, January to August 2011: descriptive epidemiology and demonstration of quarantine effectiveness. Euro Surveill 2013; 18(6). pii: 20395.

18. Gerber JS, Offit PA. Vaccines and autism: a tale of shifting hypotheses. Clin Infect Dis 2009; 48: 456-61.

19. Cliff A, Haggett P, Smallman-Raynor M. The changing shape of island epidemics: historical trends in Icelandic infectious disease waves, 1902-1988. J Historical Geogr 2009: 35: 545-67.

20. Cliff A, Haggett P. Time, travel and infection. Br Med Bull 2004; 69: 87-99.
21. Gottfredsson M, Halldórsson BV, Jónsson S, Kristiánsson M, Kristjánsson K, Kristinsson KG, et al. Lessons from the past: familial aggregation analysis of fatal pandemic influenza (Spanish flu) in Iceland in 1918. Proc Natl Acad Sci U S A 2008: 105: 1303-8.

22. [Anonymous]. Pjóðólfur. 17. maí 1882.

23. [Anonymous]. Fréttabálkur. Gestur Vestfirðingur. 1. jan. 1847: 1(1):6

24. Á.Ó. Drepsótt í Reykjavík, mislingarnir 1882. Lesbók Morgunblaðsins. 4. júní 1950, 25(21):301.

25. [Anonymous]. Dílasóttin (Mislingaveikin). Ísafold. 29. júlí 1882, 9(18):71.

26. [Anonymous]. Norðlingur. 20. apríl 1882, 6(43-44):86.

27. Landlæknir. Heilbrigðisskýrslur 1881-1890. 17-22.

28. Landlæknir. Heilbrigðisskýrslur 1881-1890. 19.

29. Landlæknir. Heilbrigðisskýrslur 1918. 51-56.

30. [Anonymous]. Brjef að austan. Norðanfari. 10. feb. 1869, $8(7-8): 15$

31. Panum PL. Iagttagelser anstillede under MæslingeEpidemien på Færøerne i Aaret 1846. Bibl Læger 1847; 3R 1:270-344.

32. Jónsson S. Sóttarfar og sjúkdómar á Íslandi 1400-1800. Hið íslenska bókmenntafélag, Reykjavík 1944.

33. [Anonymous]. Fólkstala á Íslandi 1890. Ísafold. 10. júní 1891, 18(46): 181

ENGLISH SUMMARY

\section{Extent and impact of the measles epidemics of 1846 and 1882 in Iceland}

Sandra Gunnarsdottir ${ }^{1}$, Haraldur Briem ${ }^{1,2}$, Magnús Gottfredsson ${ }^{1,3}$

Introduction: Measles have increased in incidence in some parts of the developed world in the past 10-15 years. They can be fatal and lead to severe sequelae.Measles were infrequently introduced to Iceland in the 19th century and consequently, epidemics were few but associated with an extremely high mortality. The availability of 19th century church registries enables studies on the impact of measles on mortality. Materials and methods: Historical accounts mention two major measles epidemics, starting mid-year 1846 and 1882. We analysed these two epidemics using contemporary historical sources, mainly original church registries.

Results: In the 1846 epidemic the data show a clear increase in mortality in June and reach a peak in July of 741 fatal cases total, a four-fold increase from expected baseline rate. The epidemic subsided in the ensuing five months. A cluster of measles was described in the eastern region of Iceland in 1869 but did not spread further. The epidemic of 1882 reached its peak in July, when 1084 individuals died, a five-fold increase from the expected rate. Excess mortality was highest in $\mathrm{N}$-Isafjardarsysla county, 4,7\%, and none in A-Skaftafellssysla county where the illness was described 13 years previously. The highest numbers of fatal cases in the 1882 epidemic $(64,6 \%)$ was among $0-4$ year old children. The number of fatalities among women of child-bearing age was more than two-fold compared to men; the number of births 7-9 months following the 1882 peak dropped significantly by $50 \%$.

Conclusions: This study highlights the consequences of measles following introduction into a largely susceptible population and also documents the importance of herd immunity. Information can be identified on most individual fatalities during the 1846 and 1882 measles epidemics in Iceland.

Key words: Measles, mortality, epidemic, historical sources, pregnancy.

Correspondence: Magnús Gottfreðsson magnusgo@landspitali.is

${ }^{1}$ Faculty of medicine, University of Iceland, ${ }^{2}$ Directorate of Health, ${ }^{3}$ Landspítali University Hospital 